\title{
Fiscal Policy and the Inflation Target*
}

\author{
Peter Tulip \\ Reserve Bank of Australia
}

\begin{abstract}
Low interest rates in the United States have recently been accompanied by large fiscal stimulus. However, discussions of monetary policy have neglected this fiscal activism, leading to overestimates of the costs of the zero lower bound and, hence, of the appropriate inflation target. To rectify this, I include countercyclical fiscal policy within a large-scale model of the U.S. economy. I find that fiscal activism can substitute for a high inflation target. If fiscal policy behaves as it has recently, then an increase in the inflation target is not warranted, despite increased volatility of macroeconomic shocks.
\end{abstract}

JEL Codes: E52, E62.

\section{Introduction}

The U.S. Federal Reserve has a long-run inflation target of 2 percent (Federal Open Market Committee 2012). Many considerations influence this choice, but it partly reflects a trade-off: Lower inflation has direct welfare benefits, but it also means interest rates have a greater probability of falling to their lower bound of zero. The zero lower bound is a problem because it prevents the central bank from fighting recessions with large reductions in interest rates. So the economy would be less stable with a low inflation target. For this reason, some

${ }^{*}$ A first draft of this paper was written while the author was employed at the Federal Reserve Board of Governors. I am especially grateful to John Roberts for many thoughtful, detailed suggestions that greatly improved the paper. Thanks also to the referees, Flint Brayton, Eric Engen, Glenn Follette, Mariano Kulish, Mark Lasky, David Orsmond, Dan Rees, Dan Sichel, Carl Walsh, Johannes Wieland, John Williams, participants at the IJCB conference, and many of my colleagues at the Federal Reserve Board for comments and technical assistance. Candace Adelberg and Peter Chen provided research assistance. The views presented in this paper are solely those of the author and do not necessarily represent those of the Federal Reserve Board, the Reserve Bank of Australia, or their staffs. A slightly longer version of this paper is available as Tulip (2014). Supporting material is at www.petertulip.com. Author e-mail: TulipP@rba.gov.au. 
prominent economists, such as Blanchard, Dell'Ariccia, and Mauro (2010) and Ball (2013), have argued for a higher inflation target.

Several researchers have quantified this argument. Most prominently, Reifschneider and Williams (2000) conduct stochastic simulations of the Federal Reserve's FRB/US model and conclude that the zero lower bound noticeably increases the variability of economic activity for inflation targets below 2 percent or so. Similar studies include Coenen, Orphanides, and Wieland (2004), Hunt and Laxton (2004), and Williams (2009). Billi and Kahn (2008) provide an overview. This research has played a central role in the Federal Open Market Committee's (FOMC's) earlier consideration of appropriate inflation targets judging by the transcript and staff materials for the FOMC meeting of February 1, 2005 (FOMC 2005; Elmendorf et al. 2005). These studies have been emphasized by policymakers such as Bernanke (2003) and Yellen (2009) in discussing their choice of inflation targets. Subsequent research by Coibion, Gorodnichenko, and Wieland (2012) supports similar conclusions.

A limitation of much of the policy discussions and the underlying research is that they have assumed that fiscal policy is passive, doing little to stimulate the economy (beyond automatic stabilizers) when interest rates approach zero. That assumption was consistent with both actual fiscal policy and expert policy recommendations until recently. However, as discussed below, there has been a renewed enthusiasm for active countercyclical fiscal policy on the part of both policymakers and advisers. The key finding of this paper is that this new fiscal activism substantially reduces the frequency and severity of hitting the zero bound. That should significantly lower the inflation target 1

Specifically, I develop a fiscal policy reaction function that explains recent U.S. fiscal policy at the zero bound. I then include this rule within the FRB/US model, which is a large-scale model of the U.S. economy maintained by the staff of the Federal Reserve Board, and run stochastic simulations. These simulations suggest that realistic countercyclical fiscal policy permits substantially lower

\footnotetext{
${ }^{1}$ I use the terms "active" and "passive" in their everyday sense of responsiveness to economic activity. This usage differs from Leeper's (1991) well-known definitions in which fiscal policy is "active" or "passive" depending on whether it stabilizes the debt.
} 
inflation targets for a given variability of activity. For example, I estimate that a 2 percent inflation target is consistent with a standard deviation of unemployment of 1.4 percentage points when fiscal policy is passive; but if fiscal policymakers behave as they have recently, then the same variability of unemployment could be achieved with a target of zero inflation.

In choosing an inflation target, the central bank needs to assume how fiscal policymakers and other agents will behave. My central scenario assumes that fiscal policymakers behave as they have recently. However, given the controversy over this issue, attitudes to fiscal activism might be expected to evolve. Accordingly, in section 5, I consider two alternatives to my central scenario. It may be that the recent shift toward fiscal activism is reversed and that the passivity assumed by the earlier literature remains a good guide. If the central bank does not feel it can rely on fiscal stimulus at the zero bound, it should set a higher inflation target. Alternatively, it may be that future recessions are accompanied by larger and earlier fiscal stimulus. For example, if fiscal policy were assumed to be twice as aggressive as it has been recently, then my simulations suggest that the zero bound would cease to be an important constraint on the inflation target.

The idea that fiscal activism might lower the inflation target is not new. For example, it is discussed by Reifschneider and Williams, among others. However, this effect has not been realistically modeled and its effects have not been quantified or shown to be important. That may be why policy discussions and research have overlooked it. To put this in context, Yellen (2009), Blanchard, Dell'Ariccia, and Mauro (2010), and others have emphasized the implications of changes in perceived macroeconomic volatility for the target. However, estimates I present below suggest that the change in fiscal policy is of similar importance for the inflation target as the change in volatility.

The previous analysis that comes closest to mine is Williams (2009, section IIIB). As in this paper, Williams conducts stochastic simulations of FRB/US with different inflation targets, with and without countercyclical fiscal policy. However, Williams's interest is in whether fiscal stimulus might ameliorate worst-case scenarios: he applies it to a baseline in which the funds rate is at zero 34 percent of the time (with a 2 percent inflation target). In contrast, I focus 
on scenarios that resemble mainstream projections of the U.S. economy. Furthermore, Williams's fiscal rule is illustrative rather than realistic. I develop a rule that is consistent with observed policy. Williams is frank about the limitations of his rule and calls for further research in this area. This paper is partly a response to that demand.

A secondary contribution of this paper is to develop an empirically based reaction function that describes how U.S. fiscal policy behaves near the zero bound. This may facilitate discussions of fiscal policy near the zero bound in the way the Taylor rule has done for monetary policy. Calibrating this rule to actual policy is important because one of the primary objections to the use of countercyclical fiscal policy has been that lags make it impractical (Blinder 2004). To be clear, precise estimation is not the goal and would not be feasible. Rather, my rule is intended to roughly capture the size, timing, and impact of the recent stimulus, which seems sufficient to assess the relative importance of various factors in different conditions.

Although the titles might suggest otherwise, this paper has little in common with the literature surveyed by Schmitt-Grohé and Uribe (2010) on "the optimal rate of inflation." Whereas in this paper the zero bound is of central importance to the inflation target, the research surveyed by Schmitt-Grohé and Uribe assumes that the zero bound is irrelevant. Schmitt-Grohé and Uribe justify this assumption by arguing that under optimal monetary policy the probability of hitting the zero bound is very low. However, the recent history of interest rates in the United States, Japan, and other countries suggests that under actual monetary policy, the chances of hitting the zero bound are considerable.

To be clear, this paper is not intended to evaluate alternative policies for dealing with the zero bound. That issue has been addressed elsewhere by many authors, including Woodford and Eggertsson (2004) and Mankiw and Weinzierl (2011). Rather, I take actual monetary policy, as described by a conventional policy reaction function, as given. And I use a fiscal policy reaction function that describes recent behavior. This paper examines the implications of these reaction functions for economic stability and the inflation target. Normative analysis of fiscal policy near the zero bound, including its size, timing, and composition, would be highly desirable. However, a positive analysis of recent policy behavior seems a desirable stepping stone and benchmark for that. 
Figure 1. Fiscal Stimulus Near the Zero Bound, 2001-5

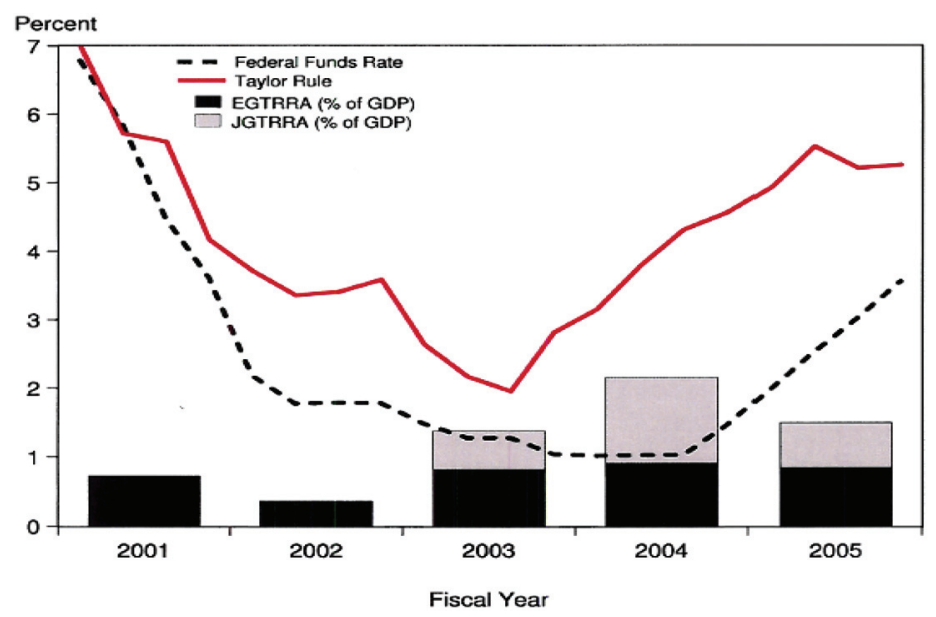

Source: "Federal Funds Rate": Federal Reserve; "Taylor Rule": CBO (2011) and author's calculations; "EGTRRA": CBO (2001, p. 8); "JGTRRA": CBO (2003, p. 18).

Similarly, this paper does not examine implications of recent innovations in monetary policy, such as asset purchases. The rationale for considering new developments in monetary policy is similar to that for considering new developments in fiscal policy, and the implications for the inflation target are qualitatively similar. I expect including asset purchases as an extra instrument of monetary policy would further allay concern about the zero bound, reinforcing one of my key results. But, at this stage, that conjecture remains to be verified.

\section{The New Regime of Fiscal Activism}

The United States has had two recent encounters with the zero bound on interest rates, in the early 2000s and following 2008. Both have been accompanied by large fiscal stimulus. This relationship is illustrated in figures 1 and 2, which show interest rates and Congressional Budget Office (CBO) estimates of the budgetary costs of major legislation intended to boost aggregate demand. Figure 1 shows CBO estimates of the budgetary cost of the Economic Growth and Tax Relief Reconciliation Act, or EGTRRA, of 2001, and the 


\section{Figure 2. Fiscal Stimulus Near the Zero Bound, 2008-12}

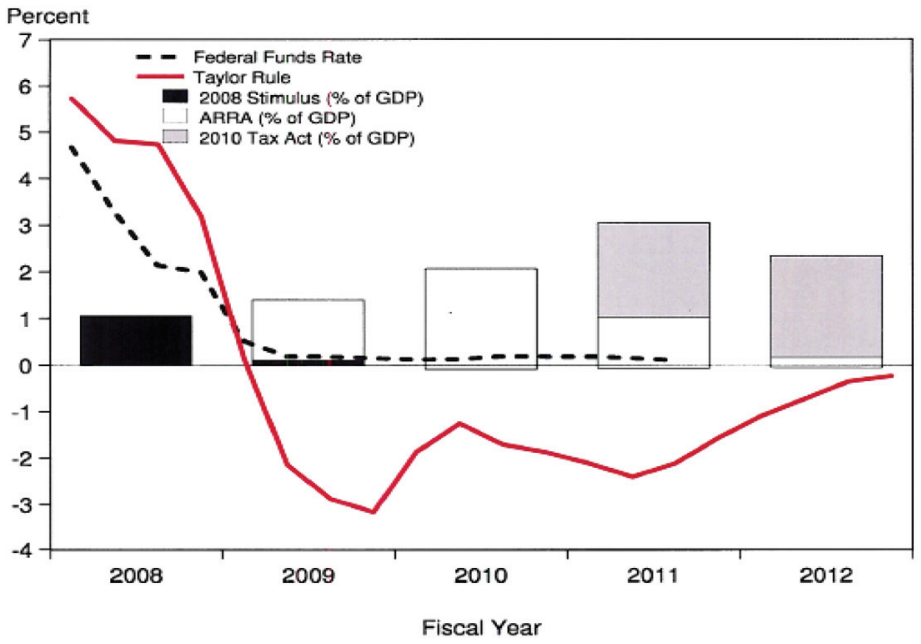

Source: "Federal Funds Rate" and "Taylor Rule": See figure 1; "2008 Stimulus": CBO (2008, p. 2); "ARRA": CBO (2009, 2011, p. 13), and Joint Committee on Taxation (2009); "2010 Tax Act": CBO (2011, p. 9).

Jobs and Growth Tax Relief Reconciliation Act, or JGTRRA, of 2003. Figure 2 shows CBO estimates of the budgetary cost of the stimulus acts of 2008, 2009, and 2010 (formally, the Economic Stimulus Act of 2008; the American Recovery and Reinvestment Act, or ARRA, of 2009; and the Tax Relief, Unemployment Insurance Reauthorization, and Job Creation Act, or TRUIRJCA, of 2010). These comprise the main stimulus legislation enacted through mid2011, with estimated effects shown through fiscal year 2012. As discussed in appendix 2, I subtract the contribution of the alternative minimum tax from the CBO estimates. For comparison, the charts also show estimates of a Taylor-type rule, described below, using estimates of the output gap from CBO (2011).

Figures 1 and 2 also show that, in each episode, fiscal stimulus was delivered in a succession of distinct packages. So, although the number of observations is small, there has been a pattern of countercyclical activism. Furthermore, stimulus has been enacted during both republican and democratic administrations.

Discretionary fiscal policy has also been strongly countercyclical in other countries. The recent global recession was accompanied by 
discretionary fiscal measures in OECD economies averaging 3.4 percent of annual GDP between 2008 and 2010 (OECD 2009, table 3.1)

The turn to fiscal activism in the United States is new. In contrast to the two most recent business cycles, fiscal policy was neutral to contractionary in previous U.S. recessions. Auerbach, Gale, and Harris (2010) provide a narrative description of this shift, noting the explicit decisions of Congress to tighten fiscal policy in 1982 and 1990. A quantitative measure of the shift can be seen, for example, in Follette and Lutz's (2010, table 6) estimates of fiscal impetus, an impact-weighted measure of the stance of fiscal policy. In the three years following the business-cycle peaks of 1969, 1973, 1980, and 1990, federal fiscal impetus averaged 0.1 percent of GDP, near its "neutral" benchmark of about 0.2 percent. In contrast, it averaged almost 1 percent of GDP after the peaks of 2000 and 2007, using data through 2009.

One reason for considering the new fiscal activism to be structural is that it has been accompanied by a parallel change in policy advice. Many economists have explained that whereas they used to be skeptical of fiscal intervention, they now view it as desirable at the zero bound. Examples include DeLong (2011) and Krugman (2011). Surveys of the state of academic thought, such as Blanchard, Dell'Ariccia, and Mauro (2010) or D. Romer (2011) suggest this change is widespread. In the words of Gary Becker (2009), "There appears to have been a huge conversion of economists toward Keynesian deficit spenders." The evolution in advice partly represents new circumstances rather than a change in opinion. According to Lawrence Summers (2010), "most economists across a broad spectrum" simultaneously believe that fiscal stimulus is effective at the lower bound but that it is not effective in normal circumstances.

Given these developments, it would now seem sensible to consider the likely effects of large fiscal stimulus when the economy next approaches the zero bound. That requires modifications to the models used to estimate the effect of the zero bound, which do not include active countercyclical fiscal policy.

\section{Modeling Countercyclical Fiscal Policy}

What kind of fiscal policy should be expected when interest rates approach the zero bound? A natural benchmark is the recent stimulus. Recent behavior is important as a guide to what is likely 
to occur in the future, as an illustration of what is practical, and as a familiar reference point for discussions of whether fiscal policy should do more or less. For these purposes, it is useful to describe this behavior with a reaction function, or rule. As noted above, it is desirable that the rule is roughly consistent with the size and timing of the recent stimulus, though precise estimation is not necessary.

The role of a policy reaction function (whether fiscal or monetary) is sometimes misunderstood. It does not mean that policymakers forsake discretion or perceive themselves to be constrained. Commitment is not necessary. Rather, it simply assumes that their response to the recent recession will be repeated in the future, in proportion to the severity of economic conditions. Nor does it mean that the rule reflects a well-accepted or understood set of principles. It more likely reflects a compromise, with which only the median policymaker agrees. The motivating assumption is that similar compromises may occur in the future.

My objective is to specify a rule that approximately fits the recent data subject to constraints that it be simple and not be obviously poor policy. A fiscal rule that is both realistic and sensible adds interest, avoids distractions, and is more likely to be stable, as policymakers are less likely to adhere to obviously flawed rules. The multiple objectives do, however, sometimes involve trade-offs. Furthermore, while I believe my judgments as to what constitutes sensible countercyclical policy are in line with mainstream economics, others would make different assumptions. I discuss these specification choices below.

Countercyclical fiscal policy is desirable when monetary policy is likely to be constrained by the lower bound. A simple indicator of that likelihood would be a low value of the actual federal funds rate. However, because the funds rate does not fall below zero, it provides no indication of the severity with which the constraint binds. Accordingly, I tie stimulus to low values of a monetary policy rule (though I acknowledge that the actual funds rate has been a better indicator of fiscal stimulus sometimes - see, for example, the 2004 observation in figure 1).

My main determinant of fiscal stimulus is a variation of the Taylor rule (often called a "Taylor (1999)" rule) that previous studies have used as a baseline:

$$
i_{t}=r+\pi_{t}+0.5\left(\pi_{t}-\pi^{*}\right)+x_{t},
$$


where $i_{t}$ denotes the prescription of the rule; $r$ is the equilibrium real interest rate, assumed to be 2.5 percent; $\pi_{t}$ is the four-quarter percent change in core PCE prices; $\pi^{*}$ is the inflation target; and $x_{t}$ is the output gap with a coefficient of 1 . The rule's inflation target, $\pi^{*}$, is exogenous. It is assumed to be 2 percent for constructing figures 1,2 , and 3 . This rule has attractive normative and positive properties (see Taylor 1999; Williams 2009). Reifschneider and Williams (2000), Elmendorf et al. (2005), and Williams (2009) present sensitivity analysis for alternative monetary rules.

Using a Taylor-type rule in my fiscal reaction function makes fiscal policy place the same weights on inflation and resource utilization as monetary policy, so the two arms of policy work in concert. In contrast, Feldstein (2007) suggests that countercyclical fiscal policy should react to three-month changes in payroll employment, whereas Orszag (2011) would tie it to the unemployment rate. Feldstein's measure would help to explain recent stimulus and has been a successful predictor of future variations in the Taylor rule. However, a problem with both suggestions is that they do not take into account inflation. For example, weakness in the labor market during the early 1980s, in 1989, or in 2000 reflected a need to reduce inflationary pressure, not a call for macroeconomic stimulus.

I assume fiscal stimulus occurs when, but only when, $i_{t}$ falls to low levels. So countercyclical fiscal policy is not called for when interest rates are unconstrained. This imparts a non-linearity that does not exist in some other fiscal rules, such as Auerbach and Gale (2009), and makes computation of model-consistent expectations difficult. The reason for the non-linearity is that, as Taylor (2000), Blinder (2004), DeLong and Summers (2012), and others discuss, discretionary countercyclical fiscal policy is not attractive when interest rates are free to adjust. In those conditions, fiscal measures are offset by the monetary policy rule and so have little medium-term effect on demand. In addition to being ineffective, discretionary countercyclical fiscal policy can be costly - it distracts scarce attention, it blurs accountability, and execution can be distortionary or otherwise imperfect - and these costs are often judged to be not worth incurring when the multiplier is low.

However, that is not to say that fiscal stimulus should wait until the zero bound actually binds (in contrast to the rule in Williams 2009). As interest rates decline toward zero, there is an increasing 
probability of hitting the constraint. Moving after this became certain would be unnecessarily late, given the asymmetry of policy mistakes. As Krugman (2008) has argued, too much fiscal stimulus can be undone by tighter monetary policy, so it does little damage. Too little fiscal stimulus is not immediately correctable if interest rates are low, so it means lower income and employment. Accordingly, I assume stimulus is proportionate to the amount the Taylor-type rule falls below a positive threshold. I assume a threshold of 2 percent, a level below which hitting the zero bound becomes a serious probability 2 This interest rate gap, $\hat{\mathrm{i}}_{t}$, is defined as

$$
\hat{\mathrm{i}}_{t}=\max \left\{2-i_{t}, 0\right\} \text {. }
$$

Choosing a threshold of 2 percent involves some trade-offs. A higher threshold would help explain the tax cuts of 2001 and 2008. In July 2001, households started receiving tax cuts worth 0.3 percent of GDP, when the outcome of the Taylor-type rule stood at 4 percent. In April 2008, households started receiving tax rebates worth 0.8 percent of annual GDP, though the outcome of the Taylor-type rule again was 4 percent. However, it is not clear that a higher threshold would be justified in terms of stabilization policy. In particular, the 2001 tax cut was originally motivated by other objectives, though the recession that preceded its passage may have convinced pivotal members of Congress to support it. A more complicated rule would probably be needed to describe these developments. However, because fiscal policy needs to be understood and supported by the political/legislative process, the stimulus rule should be simple.

I explain $d_{t}$, the deviation from baseline of the deficit as a proportion of GDP, as a function of the lagged four-quarter average of the interest rate gap.

$$
d_{t}=\beta \Sigma_{k=1}^{4} \hat{1}_{t-k} / 400
$$

${ }^{2} \mathrm{~A}$ referee points out that assuming a threshold of zero would remove an inequality condition, making it easier to compute model-consistent expectations. However, for reasons noted above, this would be neither realistic nor sensible policy: the stimulus would come too late. 


\section{Figure 3. Alternative Measures of Fiscal Stimulus, Percent of GDP}

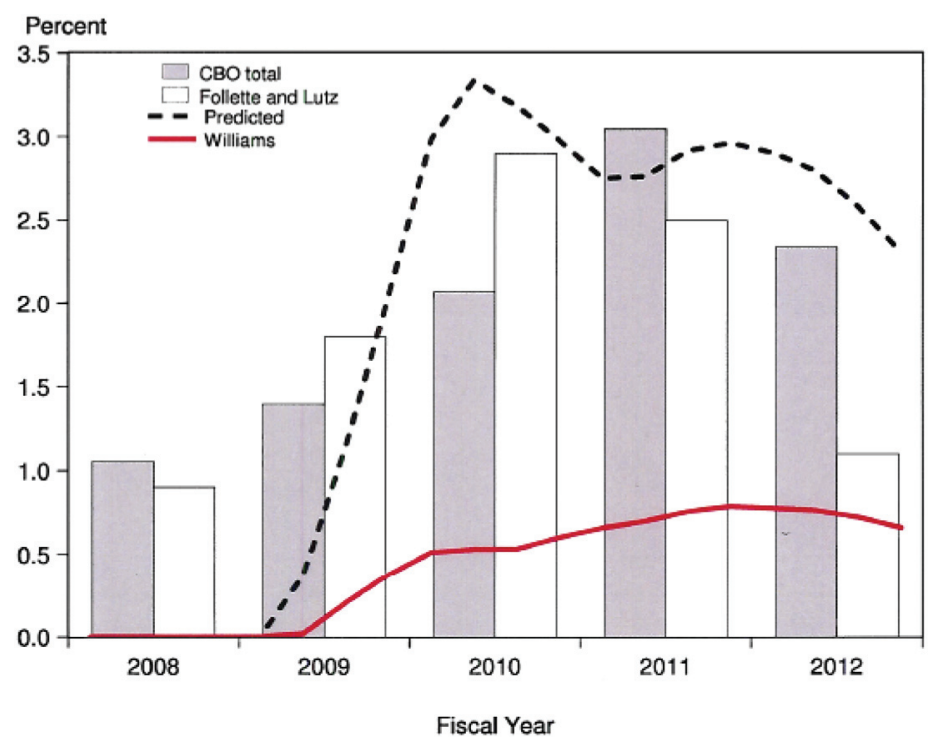

Source: "CBO Total": See figure 2. "Follette and Lutz": Follete and Lutz (2010), updated for fiscal years and the 2010 Tax Act. "Predicted": Author's calculations, CBO (2011). "Williams": Author's calculations, Williams (2009), CBO (2011).

The lags help fit the data and reflect delays in policy implementation. The parameter $\beta$ indexes the aggressiveness of fiscal policy. I show results for different values of $\beta$ in section 5 .

Summers (2008) has argued that fiscal policy near the zero bound should be "timely, targeted and temporary." As Johannes Wieland has pointed out, my rule follows Summers's advice in principle, although perhaps not in detail. The rule is timely in that stimulus begins before interest rates hit zero. It is targeted in that stimulus responds endogenously to the depth and duration of the zero bound. And it is temporary in that stimulus ends four quarters after interest rates rise above 2 percent.

Figure 3 shows various estimates of recent stimulus, measured in terms of budget cost as a percentage of GDP. Predictions from equation (3) are shown as the dashed black line. These are constructed using projections of the output gap and inflation from CBO (2011). 
These predictions use a value of $\beta=0.7$, which delivers a cumulative stimulus from 2009 to 2012 of $9 \frac{1}{2}$ percent of annual GDP, which is close to estimates of the total legislated amount of stimulus. CBObased estimates - that is, the sum of the three major acts shown in figure 2-are depicted by the dark bars. These estimates imply a cumulative stimulus of 8.9 percent (summing the 2009 and 2010 acts) or 9.9 percent (if the Economic Stimulus Act of 2008 is included as well).

The lighter bars in figure 3 show an alternative measure of fiscal stimulus by Follette and Lutz (2010), kindly updated for me by Glenn Follette, which I discuss in appendix 1. My rule also roughly approximates the Follette-Lutz estimates, which imply a total stimulus of 9.2 percent of annual GDP from 2008 through 2012. A third alternative, by Blinder and Zandi (2010), which is not shown, estimates fiscal stimulus enacted through mid-2010 (not including the 2010 Tax Act) at about 7 percent of annual GDP, marginally more than my estimates for the comparable period. Last, the solid line in figure 3 represents the fiscal rule modeled (before the event) by John Williams, which implies a stimulus that is substantially smaller and later than the other estimates 3

For the 2001-5 period, predictions of equation (3) are zero, because the Taylor rule did not fall below 2 percent. Nonetheless, that episode is relevant for establishing a pattern of fiscal activism at low interest rates. As noted above, I was unable to develop a stimulus rule that satisfactorily explained the fiscal expansion of the early 2000s. If the calibration were adjusted to place more weight on this episode, then my rule would imply bigger, earlier stimulus going forward.

Having calibrated the total stimulus, I then distribute it over the federal fiscal equations of the model. I assume that stimulus $d_{t}$ is composed of 50 percent reductions in personal taxes, 25 percent increases in federal government consumption purchases, and 25 percent increases in transfers to persons. This is a parsimonious

\footnotetext{
${ }^{3}$ I interpret Williams's equation (6) as describing the deviation of government consumption purchases (excluding employee compensation) from its trend, where the trend is 4 percent of real GDP in 2010:Q4, then grows at 2.5 percent. I use CBO estimates of the output gap and inflation, and the same Taylor-type rule I use elsewhere.
} 
approximation to recent behavior, which avoids channels of influence where FRB/US modeling is not firmly guided by the available literature, such as changes in corporate taxes or in grants to states 4.5

To illustrate, consider the equation for real transfers to persons, $T_{t}$ :

$$
T_{t}=\gamma z_{t}+s d_{t} G D P_{t-1} .
$$

$z_{t}$ is a small vector of relevant model variables, which for this equation comprises the output gap, GDP, and a stochastic trend. $\gamma$ is a vector of coefficients. $s$ represents the share of the countercyclical stimulus $d_{t}$ allocated to this instrument. So for federal taxes, transfers, and purchases, $s=.5, .25$, and .25 respectively, while for other fiscal instruments, including those of state and local governments, $s=0$. The variable GDP is self-explanatory.

The stimulus is added to equations for government spending and taxes in much the same way as in equation (4), with slight modifications to prevent the endogenous persistence in these variables from amplifying the stimulus. The modified fiscal equations of the model are presented, using FRB/US mnemonics, in appendix 2. I do not modify other equations in the model.

The $\gamma z_{t}$ terms in equation (4) and corresponding equations for other fiscal variables capture the normal response of fiscal instruments to the output gap, inflation, and other macroeconomic variables. Coefficients (including for state and local fiscal equations) are estimated from 1965 through 2007. Following previous researchers, I describe this response as "passive" or "neutral": reflecting automatic stabilizers but not discretionary fiscal policy. That terminology is not exactly accurate, because the equations also capture variations that are systematic but require legislation.

\footnotetext{
${ }^{4}$ Updated estimates from Follette and Lutz suggest that federal fiscal stimulus from 2008 through 2012 comprised 31 percent individual tax cuts, 24 percent transfers, 18 percent grants to state and local governments, 18 percent corporate tax cuts, and 8 percent "other," largely federal government purchases. Largely reflecting their different baseline, Follette and Lutz's estimates include more transfers but fewer personal tax cuts than my CBO-based estimates.

${ }^{5}$ Some readers have suggested the stimulus should comprise more spending and transfers, which have a higher "bang for the buck." However, as discussed in Mankiw and Weinzierl (2011), that view is controversial.
} 
Indexation of the alternative minimum tax to inflation and extension of unemployment benefits in recessions are examples. However, even with these effects, overall cyclical variations in fiscal instruments tend to be small and offsetting. That result is consistent with the earlier absence of discretionary fiscal policy discussed above.

An important feature of the standard FRB/US fiscal equations is that personal tax rates adjust so as to gradually stabilize the ratio of government debt to GDP. This effect means that simulated episodes of stimulus are followed by episodes of austerity. More precisely, while government spending returns to baseline as the need for stimulus dissipates, personal tax rates temporarily rise above baseline. After the results in this paper were finalized, fiscal stimulus in the United States was followed by a "sequester" that sharply reduced growth in outlays. Although the model did not predict the form of this fiscal consolidation, it did predict a substantial fiscal tightening, though comparing that with actual policy requires difficult judgments about the counterfactual. One implication of the debt-stabilization term is that the long-run average ratio of debt to GDP is not materially affected by repeated stimulus. Another implication is that the relevant "counterfactual" - that is, policy in the absence of fiscal stimulus - is what might be called "sustainable policy" rather than existing policy. The relevant estimates of recent fiscal stimulus are somewhat larger than would be constructed using a baseline of existing policy.

A key assumption underpinning my calibration of the stimulus rule is that the standard FRB/US fiscal equations approximately reflect CBO's baseline of existing legislation. If that assumption is approximately valid, then adding a stimulus calibrated to the CBO estimates to the FRB/US equations can be interpreted as describing recent behavior. I make allowances for indexation of the alternative minimum tax and unemployment benefits to improve this approximation. These issues are discussed in appendix 1 .

The above approach is not the only way that countercyclical fiscal policy could be modeled. One alternative would be to reestimate the fiscal equations of a macroeconomic model, such as FRB/US. That has advantages; for example, the counterfactual is precisely defined and complications of double-counting are avoided. But it also has substantial difficulties. One problem is distinguishing countercyclical fiscal policy from other variations in the budget (military 
operations, noise in tax receipts, the census). I do not want to model these temporary correlations as a systematic reaction to macroeconomic conditions. The scope for bias is large given that we have very few observations near the zero bound. Second, the estimates depend on equations that are specific to one particular model, which reduces their transparency, credibility, and comparability with other estimates.

\section{The FRB/US Model}

Estimates of the effect of fiscal stimulus require a macroeconomic model. I use the FRB/US model of the U.S. economy, one of the main macroeconometric models used at the Federal Reserve Board of Governors. This model has been used in some key contributions on the setting of the inflation target (Reifschneider and Williams 2000; FOMC 2005; Williams 2009), though without countercyclical fiscal policy. It has also played a prominent role in assessing the consequences of fiscal stimulus (Romer and Bernstein 2009; CBO 2010; Coenen et al. 2012), though not in a stochastic setting.

FRB/US differs from many models published in textbooks and academic journals in that it is not designed for expositional purposes. Rather, it is intended to provide a credible basis for policy advice 6 That, in turn, requires closely fitting the data and paying detailed attention to the various transmission mechanisms that policymakers regard as important. As a result, the model is large and detailed. It contains approximately 500 variables and 170 estimated equations. Unfortunately, that makes the model something of a black box to outsiders.

It is not possible to document the model here. Rather, interested readers are referred to descriptions published elsewhere. Brayton and Tinsley (1996) provide the most detailed overview. Reifschneider and Williams (2000) provide a summary that focuses on the zero bound. Elmendorf and Reifschneider (2002) discuss fiscal multipliers. Coenen et al. (2012) compare fiscal multipliers of FRB/US to

\footnotetext{
${ }^{6}$ For regular applications of FRB/US, see the alternative scenarios and confidence intervals typically published around page I-17 in each Greenbook presented to the FOMC, available at www.federalreserve.gov/monetarypolicy/fomchistorical2005.htm.
} 
those of other structural models used by policymaking institutions. The references in these papers provide further information.

In brief, the model is designed and revised with the intent of closely fitting the data. The main behavioral relationships are derived from explicit optimization problems, under the assumption of costly adjustment. Most equations are estimated individually, with explicit expectational terms. When it is difficult to explain the data with optimizing behavior, further ad hoc terms are added. For example, the consumption equations include rule-of-thumb behavior. For estimation, most operational work, and this paper, expectations are determined by small-scale vector autoregressions (VARs). However, in deterministic settings the model can also be solved under model-consistent expectations.

The channels through which monetary and fiscal policy work in FRB/US are summarized by intermediate macroeconomics textbooks (for example, Mankiw 2010, chapter 10). For more detail, consider as an illustration the consumption response to a reduction in taxes or an increase in transfers. Rule-of-thumb households (accounting for about one-quarter of total private consumption) are assumed to increase their consumption immediately. Other households raise their consumption, somewhat more gradually, to match the increase in perceived permanent income. Households are not assumed to have perfect foresight regarding the duration of the increased income. Rather, they regard their permanent income as the annuitized present value (calculated with a high discount rate) of the sum of expected wages, taxes, transfers, and so on, with expectations being the predictions of small-scale VARs. So the contribution of transfers to perceived permanent income, for example, reflects the estimated persistence of transfers in the historical data. Normally, the monetary policy rule would increase interest rates in response to the increase in consumption, in turn raising longer-term rates and the exchange rate and lowering equity prices. However, at the zero bound, these offsetting effects are greatly muted. FRB/US does not include an effect of government debt on bond risk premia, explicit "Ricardian equivalence" effects, or hysteresis in the labor market.

In deterministic settings, the model can be solved assuming that households know how long a zero-bound episode, and hence the fiscal stimulus, will last. In stochastic settings, alternative assumptions are needed. In my simulations, households are assumed to expect 


\section{Table 1. FRB/US Fiscal Multipliers at Fixed Nominal Funds Rate}

Effect on Level of Real GDP (Percent Deviation from Baseline) of a Sustained Change in Fiscal Variables by 1 Percent of GDP

\begin{tabular}{|c|c|c|}
\hline & $\begin{array}{c}\text { After Four } \\
\text { Quarters }\end{array}$ & $\begin{array}{c}\text { After Twelve } \\
\text { Quarters }\end{array}$ \\
\hline $\begin{array}{l}\text { Government } \\
\text { Purchases }\end{array}$ & 0.99 & 1.22 \\
\hline $\begin{array}{l}\text { Reduction in } \\
\text { Personal } \\
\text { Tax Receipts }\end{array}$ & 0.31 & 0.56 \\
\hline Transfers & 0.42 & 0.50 \\
\hline
\end{tabular}

historical correlations to persist, even though policy has changed. In principle, this assumption is susceptible to the Lucas critique, and I discuss it in the working paper version of this paper (Tulip 2014).

Any macroeconomic model rests on a large number of debatable assumptions. One way of assessing these assumptions is by examining the model's multipliers. A wide range of FRB/US multipliers have been publicly documented; see, for example, Brayton and Tinsley (1996) or footnote 6. For this paper the fiscal multipliers are particularly relevant. Table 1 shows the estimated response of real GDP to sustained variations in key fiscal variables with nominal interest rates held fixed. As a guide to interpretation, estimates in the top row imply that if government purchases were to deviate from baseline by 1 percent of GDP for the duration of the experiment, then the level of GDP would be 0.99 percent above baseline after four quarters and 1.22 percent above baseline after twelve quarters.

Estimation of fiscal multipliers is controversial and subject to uncertainty. I do not wish to enter this debate here, beyond some brief comments as to why the estimates in table 1 provide an interesting and relevant benchmark. The FRB/US multipliers are similar to many other estimates that assume constant nominal interest rates. For example, a survey by the OECD (2009, chapter 3 ) concluded "a review of the evidence ... typically suggests a first-year government 
spending multiplier of slightly greater than unity, with a tax cut multiplier of around half that." Overviews of the literature by C. Romer (2011), D. Romer (2011), and DeLong and Summers (2012) conclude that fiscal multipliers are substantial. Coenen et al. (2012) present a more detailed comparison of structural (mainly DSGE) models used by central banks, international organizations, and academics; they found FRB/US fiscal multipliers at fixed nominal interest rates to be similar to those of other models. As noted above, FRB/US multipliers have been one of the main sets of estimates relied upon by policymakers. The CBO (2010, appendix) compares fiscal multipliers from models like FRB/US with other estimates in the literature and concludes that the FRB/US multipliers are a useful basis for policy in current conditions, 7

Cogan et al. (2010) have argued that FRB/US multipliers are too high. Part of their argument is that the FRB/US model is "Old Keynesian" and out of step with modern modeling techniques. However, the extent to which FRB/US is "old fashioned" and whether or not this would be a problem are debatable. More important, Coenen et al. (2012, figure 7) find that FRB/US multipliers are similar to those of recent DSGE models, including the model used by Cogan et al. (2010). As Woodford (2011) and Coenen et al. (2012) discuss, the apparent disagreement occurs because Cogan et al. (2010) compare multipliers like those in table 1 with multipliers that assume government spending is expected to substantially outlast the zero bound. The possibility that stimulus measures may outlive their rationale is an important concern, but it is not the policy I am considering here.

\section{The Effect of Fiscal Stimulus}

To consider the effect of fiscal stimulus, I run repeated stochastic simulations of FRB/US about its long-run steady state. I follow the

\footnotetext{
${ }^{7}$ The estimates in table 1 differ from FRB/US multipliers published elsewhere, given that my purposes and context are slightly different. For example, my multipliers are higher than FRB/US multipliers that assume monetary policy follows a Taylor-type rule, for example, if the zero bound is explicitly expected to stop binding soon. My multipliers are lower than estimates that assume the zero bound is expected to last many years.
} 
approach discussed by Reifschneider and Williams with a few variations. Whereas Reifschneider and Williams use a linearized version of the model with model-based expectations, I use the non-linear form with VAR expectations. Assuming VAR expectations will strike many readers as unusual for an analysis of policy rules. However, as I discuss in the working paper version of this paper (Tulip 2014), the differences between VAR-based and model-based expectations do not seem to be large for this particular exercise. For example, multipliers for fiscal measures sustained for representative zero-bound episodes (a year or two) are about the same. And there are both practical and conceptual reasons for preferring VAR expectations to model-based expectations. In particular, the economy hits the zero bound infrequently, so learning from experience would take decades. So data-based expectations may be a reasonable assumption for a horizon relevant to the behavior of a policy rule.

I use the 2010 vintage of the model, in which most equations, including VAR-based expectations, are estimated through 2009. I randomly draw residuals from sixty-five key model equations from the period 1968 through 2009, then simulate the model over 120 years, discard the first 20 years, store, and repeat 500 times 8 I use a block bootstrap with block size of four quarters 9 That means that serially correlated surprises, such as the financial crisis of 2008-9, are represented in the simulations. To avoid double-counting the recent stimulus, the fiscal equations of the model are only estimated through 2007 and bootstrapped residuals for fiscal variables are set at zero after 2008:Q1. The aim of this approach is to generate 50,000 years of artificial data with the same conditional correlations (across variables and across time), covariances, skewness, and kurtosis as the last forty-odd years of U.S. history. Unusual events, such as the financial crisis of 2008, or the oil price increase of 1973 , are effectively assumed to be once-in-forty-years events. Alternatively,

\footnotetext{
${ }^{8}$ About 3 percent of simulations of 120 years fail - that is, once every 4,000 years. Typically, this is because the model wanders off to an inadmissible regionfor example, with a negative income or expenditure share. When this happens, I disregard the simulation.

${ }^{9}$ Whereas a basic bootstrap draws one quarter of observations at a time, the block bootstrap draws blocks of consecutive quarters, so as to capture unmodeled leads and lags.
} 
they can be considered to be representative of a larger class of less frequent events.

The simulations generate distributions of many key macroeconomic variables that are similar to those seen in recent U.S. history. For example, the standard deviation of the unemployment rate is 1.3 percentage points in simulations with high inflation targets. This compares with an actual standard deviation of the gap between the unemployment rate and the model's effective NAIRU of 1.4 percentage points from 1968 through 2009. Because the simulations are conditional on inflation targets that differ from those implicitly used in the past, the volatility of nominal variables is harder to compare with the data. However, the frequency of zero-bound episodes in my simulations (table 2, row 1) is about the same as that of Coibion, Gorodnichenko, and Wieland (2012, figure 1), which, they argue, matches U.S. experience. With respect to the distribution of variables conditional on a given starting point, Reifschneider and Tulip (2007, table 9) show that FRB/US stochastic simulations are similar to real-time errors from major U.S. macroeconomic forecasters.

The top panel of table 2 shows key summary statistics for simulations with no unusual fiscal stimulus; that is, $\beta$ in equation (3) equals zero. As the inflation target approaches the lower bound, monetary policy is constrained more often. For example, as shown in the top row, interest rates are zero 8 percent of the time with an inflation target of 2 percent, rising to 14 percent of the time if the target is 1 percent. And, as shown in the second and third rows, the severity of these episodes, as measured by their duration or the standard deviation of unemployment, also increases at low inflation rates. As reported by Reifschneider and Williams (2000, table 1) the volatility of other variables, such as the inflation rate or interest rates, is not greatly affected by the inflation target.

The simulations reported in the top panel of the table are in line with previous research using FRB/US. The standard deviation of unemployment is higher than that reported by Reifschneider and Williams, but that is accounted for by the difference in sample period, which here includes the recent financial crisis. If this episode is excluded, the results are essentially the same, as discussed in section 6.

The upper panel assumes that fiscal policy behaves passively, in line with historical patterns and earlier research. In contrast, the 


\section{Table 2. Simulated Outcomes at Different Inflation Targets}

\begin{tabular}{|c|c|c|c|c|}
\hline & \multicolumn{4}{|c|}{ Inflation Target } \\
\hline & 0 Percent & 1 Percent & 2 Percent & 4 Percent \\
\hline \multicolumn{5}{|c|}{ A. Without Stimulus } \\
\hline $\begin{array}{l}\text { Proportion of Time at } \\
\text { Zero Bound }\end{array}$ & .25 & .14 & .08 & .03 \\
\hline $\begin{array}{l}\text { Median Length of Zero- } \\
\text { Bound Episode } \\
\text { (quarters) }\end{array}$ & 8 & 6 & 5 & 4 \\
\hline $\begin{array}{l}\text { Standard Deviation of } \\
\text { Unemployment Rate } \\
\text { (percentage points) }\end{array}$ & 1.71 & 1.51 & 1.38 & 1.28 \\
\hline $\begin{array}{l}\text { Standard Deviation of } \\
\text { Debt/GDP } \\
\text { (percentage points) }\end{array}$ & 3.7 & 3.4 & 3.2 & 2.9 \\
\hline \multicolumn{5}{|c|}{ B. With Recent Stimulus } \\
\hline $\begin{array}{l}\text { Proportion of Time at } \\
\quad \text { Zero Bound }\end{array}$ & .20 & .11 & .06 & .02 \\
\hline $\begin{array}{l}\text { Median Length of Zero- } \\
\text { Bound Episode } \\
\text { (quarters) }\end{array}$ & 6 & 5 & 4 & 3 \\
\hline $\begin{array}{l}\text { Standard Deviation of } \\
\text { Unemployment Rate } \\
\text { (percentage points) }\end{array}$ & 1.39 & 1.29 & 1.26 & 1.23 \\
\hline $\begin{array}{l}\text { Standard Deviation of } \\
\text { Debt/GDP } \\
\text { (percentage points) }\end{array}$ & 5.1 & 4.3 & 3.7 & 3.1 \\
\hline
\end{tabular}

lower panel shows the effect of countercyclical fiscal policy - that is, with $\beta=0.7$. I interpret this calibration as describing recent policy, and label it as such. As can be seen by comparing the upper and lower panels, countercyclical fiscal policy reduces the frequency and severity of zero-bound episodes. Figure 4 plots the standard deviation of the unemployment rate for different inflation targets. The 
Figure 4. Unemployment Variability at Different Inflation Targets

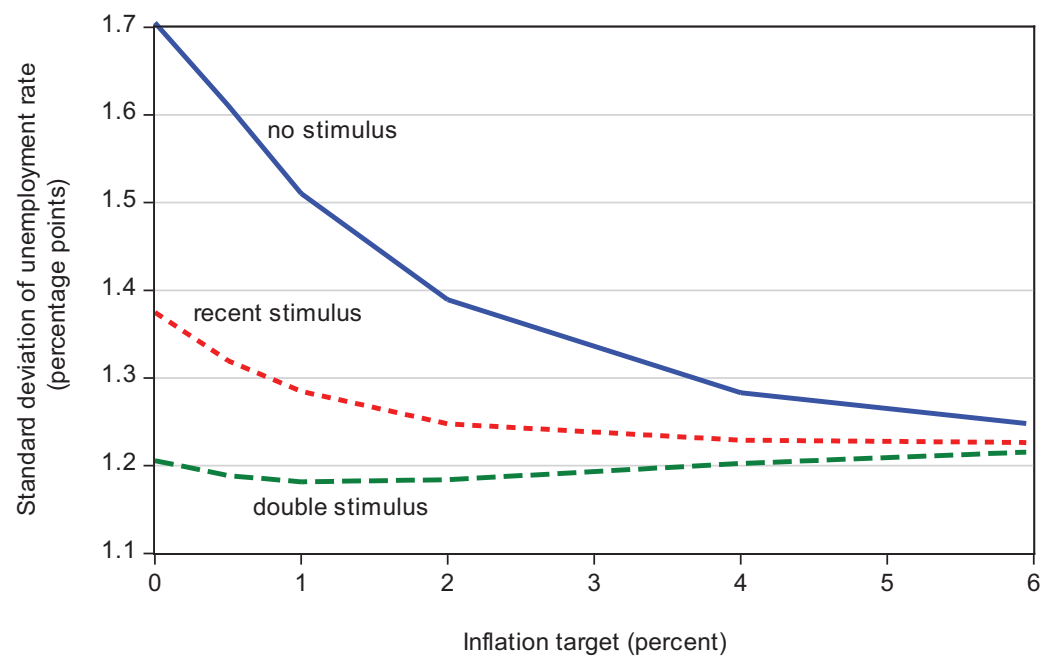

Source: Author's calculations.

lines labeled "no stimulus" and "recent stimulus" represent simulations with $\beta$ equal to zero and 0.7 , respectively. With active fiscal policy, the economy is more stable, especially at low inflation rates.

The difference between the lines labeled "no stimulus" and "recent stimulus" provides a measure of the benefits from countercyclical fiscal policy. If fiscal policy is passive, then an inflation target of 2 percent is associated with a standard deviation of the unemployment rate of 1.39 percentage points. However, if fiscal policy behaves as it has recently, then the same variability of unemployment could be achieved with an inflation target of zero. Put another way, countercyclical fiscal policy is estimated to lower the standard deviation of the unemployment rate by 9 percent at a 2 percent inflation target or by 19 percent at a zero inflation target.

As noted above, the personal tax rate equation in FRB/US adjusts taxes so as to stabilize the ratio of government debt to GDP around its assumed target, set at 55 percent in the baseline. Active countercyclical fiscal policy does not change the average ratio of debt/GDP but it does increase its variability, as shown by comparing the last row in each panel of table 2. It is not clear that a 
government that borrows in its own currency, such as the United States, should be especially concerned about these variations, and the model assumes they are costless. However, they may be a political constraint on active fiscal policy.

A third alternative, labeled "double stimulus" in figure 4, sets $\beta=1.4$, twice the previous value. According to these estimates, this more aggressive fiscal policy almost eliminates economic variability arising from the zero bound. Such a policy may seem attractive; however, a discussion of optimal fiscal policy would also consider costs, and is beyond the scope of this paper. An interesting feature of the "double stimulus" simulation is that unemployment is slightly more stable at low inflation (1 or 2 percent) than at higher rates. Presumably this is because this particular fiscal rule - which only kicks in at low interest rates - is more stabilizing than the baseline monetary policy rule.

From the perspective of monetary policy, it seems appropriate to take current fiscal policy as given. In that sense, a frontier such as the "recent stimulus" line in figure 4 can be considered as a possible menu from which central bankers might choose. This issue is explored in section 6 . From a broader perspective, society needs to choose between different combinations of fiscal policy and the associated inflation target. One option would be fiscal policy resembling that seen recently with a moderate inflation target; another option would be more aggressive fiscal policy with a lower inflation target.

The results in figure 4 span a wide range of possible outcomes, which reduces the need for detailed sensitivity analysis. In qualitative terms, alternative modeling choices affect the results in fairly straightforward ways. For example, if fiscal policy multipliers were smaller than FRB/US estimates, or if the stimulus were smaller than my "recent stimulus" simulations, those simulations would more closely resemble the "no stimulus" experiment. Such an outcome would be likely if, for example, fiscal stimulus placed more weight on low-multiplier instruments, such as tax cuts, or if stimulus were expected to considerably outlast the zero bound, giving rise to offsetting increases in bond yields. Alternatively, if fiscal policy were more potent, timely, or aggressive than assumed in the "recent stimulus" simulations, those results would move toward those depicted by the "double stimulus" simulations. Such an outcome would be likely if the fiscal rule placed more weight on the 2001 and 2008 fiscal measures. 
Perhaps a more important sensitivity is to the assumed volatility of economic shocks, addressed in the following section.

\section{Lessons of the Crisis}

The previous section suggested that researchers and policymakers may have overestimated the optimal inflation target by neglecting countercyclical fiscal policy. However, that is not the only lesson from the recent crisis. We have also learned, for example, that macroeconomic shocks are more volatile. Williams (2009), Yellen (2009), and Blanchard, Dell'Ariccia, and Mauro (2010) have discussed having a higher inflation target because of this increase in perceived volatility. This raises the question of how changes in fiscal activism and volatility should be balanced against each other. Put another way, suppose a policymaker regarded an inflation target of, say, 1.5 percent as appropriate before the recent recession (as suggested by Elmendorf et al. 2005 or Yellen 2006, among others). Given what has been learned since then, what might be his or her new target?

Figure 5 provides one possible answer. The dashed lines represent the trade-offs between inflation and instability reproduced from figure 4, labeled as before. To illustrate how a central banker in early 2007 might have perceived the trade-off, the solid line labeled "as of 2007" is constructed assuming passive fiscal policy and drawing residuals from the period 1968 to 2006 . That curve is essentially the same as the estimates of Reifschneider and Williams, adjusting for measurement differences 10 This is intended to be a simple approximation to the menu from which policymakers may have chosen a target of 1.5 percent.

The thin dotted curve drawn through point A reflects a hypothetical indifference curve. The preferences that might give rise to a choice like A can be represented by the loss function

$$
L=\left(\pi^{*}-0.5\right)^{2}+22 \sigma^{2},
$$

\footnotetext{
${ }^{10}$ See their presentation to the FOMC on January 29, 2002, page 161 of transcript. My estimates are about the same as those in row 2 of the middle panel if the inflation rate is shifted half a percentage point, the average difference between CPI inflation and PCE inflation.
} 


\section{Figure 5. Different Trade-Offs between Inflation and Unemployment Instability}

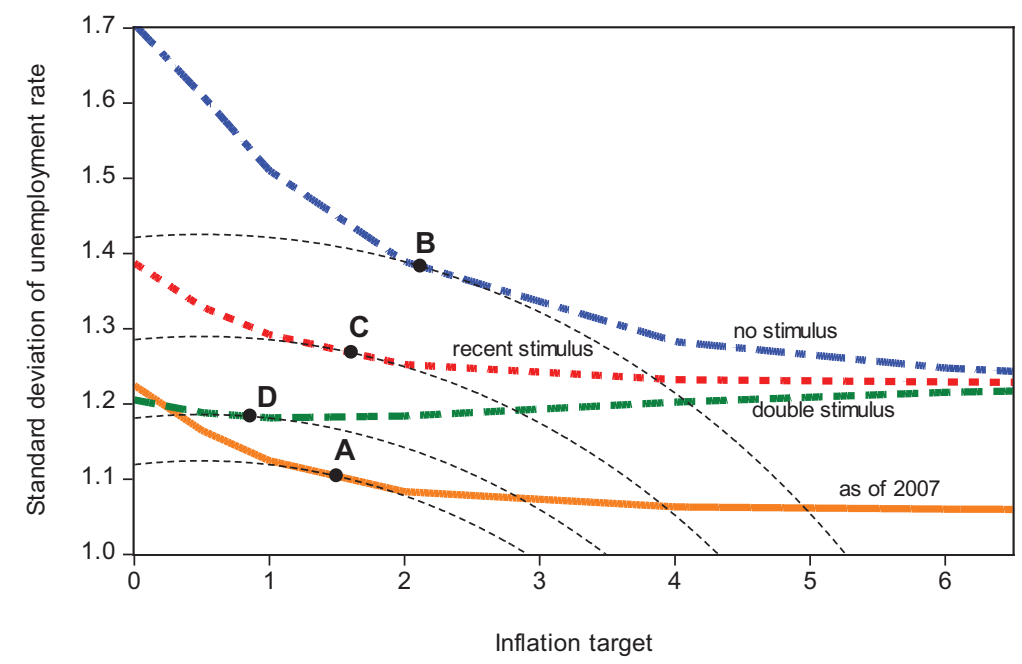

Source: Author's calculations.

where $\pi^{*}$ is the inflation target (not deviations from the target, as often appears in discussion of stabilization policy), the parameter 0.5 is Elmendorf et al. (2005)'s estimate of the measurement bias in the PCE price series, $\sigma$ is the standard deviation of the unemployment rate, and the coefficient 22 is chosen so as to minimize the loss at A. For simplicity, I assume that other factors that affect preferences over inflation objectives, such as tax distortions or downward nominal wage rigidity, are roughly offsetting. At point A, the central banker has an inflation target of 1.5 percent, which implies a standard deviation of the unemployment rate of 1.10 percentage points. Such a choice implies that an extra percentage point of steady-state inflation is worth 0.04 percentage point extra standard deviation of unemployment. Indifference curves through points B, C, and D represent the same preferences.

Under these assumptions, a central banker who perceives that volatility has increased, but that fiscal policy will remain passive, might choose a point such as B, with an inflation target of 2 percent. The difference between points A and B illustrates the sensitivity of this approach to changes in estimates of volatility. 
Were the central banker also to believe that recent fiscal stimulus is likely to be repeated, he may choose a point like $\mathrm{C}$, also with a target of $1 \frac{1}{2}$ percent. According to the model's estimates, the inflation target is about the same as the pre-recession choice, because the change in fiscal policy offsets the increase in perceived volatility. Thus, although changes in volatility are important for the choice of inflation target, whether fiscal policy is active or passive is of similar importance.

If fiscal policy were even more aggressive, the inflation target could be lower still. For example, a fiscal policy that is twice as aggressive as recently would imply point $\mathrm{D}$, with an inflation target of 0.9 percent. For such an aggressive fiscal policy, the trade-off between steady-state inflation and instability is very flat. In these conditions, the inflation target is essentially decided by considerations other than the zero bound, such as estimates of measurement bias.

The examples above are illustrative and omit some other important lessons from the recent crisis. For example, we have also learned that central banks are likely to purchase long-term securities so as to reduce bond premiums. Furthermore, point A may not be the best starting point, as suggested by Billi (2011) or Coibion, Gorodnichenko, and Wieland (2012). But notwithstanding these caveats, the simulations shown in figure 5 suggest that the inflation target should not increase simply because perceived volatility has increased.

\section{Directions for Future Research}

The simulations shown in figure 4 imply that countercyclical fiscal policy, such as we have just seen, can be expected to stabilize the economy, substituting for a higher inflation target.

This result could be developed and refined in several directions. One variation would be to assume model-consistent expectations. However, as discussed in Tulip (2014), it is not clear that this would affect the results. A second useful extension would be to incorporate non-conventional monetary policy, as discussed by Chung et al. (2012). This should be included for essentially the same reasons as those I gave for including fiscal activism. A third important challenge is to determine how large will be the shocks hitting the economy. As 
discussed in reference to figure 5, the inflation target is sensitive to this assumption unless fiscal policy is very aggressive. Related to this point, interest rates have remained at the zero bound for longer than was expected when my results were finalized. That does not pose problems for the fiscal rule, as extra stimulus measures were also introduced. However, it does highlight the sensitivity of assessments of economic volatility to the sample period from which shocks are drawn.

My simulations quantify substantial benefits from systematic countercyclical fiscal policy. However, in order to make fiscal policy recommendations, it would need to be argued that these benefits exceed the costs. The current version of FRB/US is not specified so as to address this question, because the costs of countercyclical fiscal policy in FRB/US are simply assumed to be unimportant. For example, perceptions of default probabilities do not depend on debt levels, labor supply does not respond to variations in tax rates, and my stimulus rule did not include measurement or other errors. Although these assumptions may be appropriate for many purposes, a more general model would be able to more persuasively address the issue of optimal fiscal policy.

\section{Appendix 1. Measurement of Recent Stimulus}

For reasons given in section 3 , it is desirable to calibrate my stimulus rule, equation (3), to recent behavior. Estimates of recent stimulus legislation by the CBO, by Follette and Lutz, and by Blinder and Zandi (through mid-2010) are similar. Notwithstanding this agreement, some issues of measurement and definition may be worth noting.

To avoid double-counting, I want to exclude measures that the standard FRB/US equations predict would have occurred anyway. The main component of the CBO estimates to which this applies is indexation of the alternative minimum tax (AMT), which I subtract from the published CBO totals to give the series plotted in figures 2 and 3. Follette-Lutz and Blinder-Zandi make similar adjustments.

Although the FRB/US equations for transfers have a substantial cyclical effect, they do not explain all of the recent increase, the shortfall being about $1 \frac{1}{2}$ percent of GDP. Fortuitously, that roughly corresponds to increases in transfers that have been legislated in the 
three large bills. So restricting estimates of stimulus to the three large bills is a crude but simple approximation to the increase in transfers that is additional to the FRB/US equations.

The biggest difference between the CBO estimates and FolletteLutz is the extension of "middle-class tax cuts" that were scheduled to expire at the end of 2010. They are included within the CBO estimates, which are relative to a counterfactual of "existing legislation," but excluded from Follette-Lutz, which is relative to a counterfactual of "existing policy." In contrast, my implicit counterfactual is "predictions of FRB/US equations" or what might be called "sustainable policy," which call for a large increase in taxes around this time in order to stabilize the debt. So the CBO estimates happen to provide a measure of stimulus in 2011 and 2012 that is closer to my purposes.

Less important, but high profile, are asset purchases such as the Troubled Asset Relief Program, or TARP. I do not include this as systematic countercyclical policy largely because the net present value of asset purchases is highly uncertain and their multiplier is widely assumed to be quite low. So repetition of future TARP-like programs would have little effect on the cyclical behavior of the economy.

There are other recent programs that might be considered to be countercyclical fiscal policy, including Cash for Clunkers, the homebuyers tax credit, and so on. But the total budgetary cost of these measures was small (see Blinder and Zandi 2010, table 10).

\section{Appendix 2. FRB/US Fiscal Equations}

This appendix presents key equations in the fiscal block of FRB/US, modified to include the effects of countercyclical stimulus, $d_{t}$ as defined in equation (3). The model's full equation list is available at www.petertulip.com.

Real transfers (GFT) equal the trend share (GFTRT) of transfers in potential output (XGDPT) plus deviations from that trend (GFTRD) plus a quarter of the stimulus, $d_{t}$ *XGDP, where XGDP is real GDP:

$$
\mathrm{GFT}=(\mathrm{GFTRD}+\mathrm{GFTRT})^{*} \mathrm{XGDPT}+.25^{*} d_{t}{ }^{*} \mathrm{XGDP}(-1)
$$


Real government consumption purchases before the stimulus, excluding employee compensation (EGFOBASE) is a function of own lags, a stochastic time trend (EGFOT), and the output gap (GDPGAP):

$$
\begin{aligned}
& \mathrm{D}(\operatorname{LOG}(\mathrm{EGFOBASE}))=-.0026-.17^{*} \mathrm{LOG}(\operatorname{EGFOBASE}(-1) / \\
& \operatorname{EGFOT}(-1))-.24^{*} \mathrm{D}(\operatorname{LOG}(\operatorname{EGFOBASE}(-1))) \\
& -.11^{*} \mathrm{D}(\operatorname{LOG}(\operatorname{EGFOBASE}(-2)))+1.78^{*} \mathrm{D}(\operatorname{LOG}(\operatorname{EGFOT})) \\
& -00039^{*} \operatorname{GDPGAP}(-1)+.0012^{*} \operatorname{GDPGAP}(-2)
\end{aligned}
$$

EGFO is EGFOBASE plus a quarter of the total stimulus, in real dollars. The separation of EGFO and EGFOBASE ensures that the endogenous persistence in EGFOBASE does not amplify the stimulus:

$$
\mathrm{EGFO}=\mathrm{EGFOBASE}+.25^{*} d_{t}{ }^{*} \mathrm{XGDP}(-1) .
$$

Nominal personal tax receipts (TFPN) equal the tax rate (TRFP) times taxable income (YPNADJ) minus half the stimulus in nominal dollars:

$$
\mathrm{TFPN}=\mathrm{TRFP}^{*} \mathrm{YPNADJ}-.5^{*} d_{t}{ }^{*} \mathrm{XGDPN}(-1) .
$$

The tax rate (TRFP) is a function of the trend tax rate (TRFPT), own lags, and the output gap (GDPGAP). I shock TFPN rather than TRFP so that the endogenous persistence in TRFP does not amplify the stimulus:

$$
\begin{aligned}
\mathrm{TRFP}= & \mathrm{TRFPT}+.57^{*}(\operatorname{TRFP}(-1)-\mathrm{TRFPT}(-1)) \\
& +.35^{*}(\operatorname{TRFP}(-2)-\operatorname{TRFPT}(-2)) \\
& +.00034^{*} \operatorname{GDPGAP}(-1) .
\end{aligned}
$$

The trend tax rate (TRFPT) adjusts to stabilize debt (GFDBTN) at 55 percent of nominal GDP (XGDPN):

$$
\begin{aligned}
\text { TRFPT }= & \operatorname{TRFPT}_{t-1}+0.05^{*}\left(\operatorname{GFDBTN}_{t-1} / \mathrm{XGDPN}_{t-1}-.55\right) \\
& +0.5^{*} \mathrm{D}\left(\mathrm{GFDBTN}_{t-1} / \mathrm{XGDPN}_{t-1}-.55\right) .
\end{aligned}
$$




\section{References}

Auerbach, A. J., and W. G. Gale. 2009. "Activist Fiscal Policy to Stabilize Economic Activity." In Financial Stability and Macroeconomic Policy, 327-74. Federal Reserve Bank of Kansas City. Auerbach, A. J., W. G. Gale, and B. H. Harris. 2010. "Activist Fiscal Policy." Journal of Economic Perspectives 24 (4): 141-64.

Ball, L. 2013. "The Case for Four Percent Inflation." Central Bank Review 13 (2): 17-31.

Becker, G. 2009. "On the Obama Stimulus Plan." January 11. Available at http://becker-posner-blog.com/2009/01/on-the-obamastimulus-plan-becker.html.

Bernanke, B. S. 2003. Panel discussion remarks at the $28^{\text {th }}$ Annual Policy Conference on Inflation Targeting: Prospects and Problems, Federal Reserve Bank of St. Louis, St. Louis, Missouri, October 17.

Billi, R. 2011. "Optimal Inflation for the US Economy." American Economic Journal: Macroeconomics 3 (3): 29-52.

Billi, R., and G. A. Kahn. 2008. "What Is the Optimal Inflation Rate?" Economic Review (Federal Reserve Bank of Kansas City) (Second Quarter): 5-28.

Blanchard, O., G. Dell'Ariccia, and P. Mauro. 2010. "Rethinking Macroeconomic Policy." IMF Staff Positional Note No. 10/03.

Blinder, A. S. 2004. "The Case Against the Case Against Fiscal Policy." In The Macroeconomics of Fiscal Policy, ed. R. Kopke, G. Tootell, and R. Triest. MIT Press.

Blinder, A. S., and M. Zandi. 2010. "How the Great Recession Was Brought to an End." July 27. Available at http://www.economy. com/mark-zandi/documents/End-of-Great-Recession.pdf.

Brayton, F., and P. Tinsley. 1996. "A Guide to FRB/US: A Macroeconomic Model of the United States." FEDS Paper No. 199642. Washington, DC: Board of Governors of the Federal Reserve System.

Chung, H., J.-P. Laforte, D. Reifschneider, and J. C. Williams. 2012. "Have We Underestimated the Likelihood and Severity of Zero Lower Bound Events?" Journal of Money, Credit and Banking 44 (S1): 47-82.

Coenen, G., C. J. Erceg, C. Freedman, D. Furceri, M. Kumhof, R. Lalonde, D. Laxton, J. Lindé, A. Mourougane, D. Muir, 
S. Mursula, C. de Resende, J. Roberts, W. Roeger, S. Snudden, M. Trabandt, and J. in "t Veld. 2012. "Effects of Fiscal Stimulus in Structural Models." American Economic Journal: Macroeconomics 4 (1): 22-68.

Coenen, G., A. Orphanides, and V. Wieland. 2004. "Price Stability and Monetary Policy Effectiveness when Nominal Interest Rates Are Bounded at Zero." Advances in Macroeconomics 4 (1): 1534-6013 (article 1).

Cogan, J. F., T. Cwik, J. B. Taylor, and V. Wieland. 2010. "New Keynesian versus Old Keynesian Government Spending Multipliers." Journal of Economic Dynamics and Control 34 (3): 281-95.

Coibion, O., Y. Gorodnichenko, and J. Wieland. 2012. "The Optimal Inflation Rate in New Keynesian Models: Should Central Banks Raise Their Inflation Targets in Light of the Zero Lower Bound?" Review of Economic Studies 79 (4): 1371-1406.

Congressional Budget Office. 2001. The Budget and Economic Outlook: An Update. August.

- 2003. The Budget and Economic Outlook: An Update. August.

. 2008. H.R. 5140 Economic Stimulus Act of 2008. Congressional Budget Office Cost Estimate, February 11.

. 2009. Estimated Cost of the Conference Agreement for H.R.

1, The American Recovery and Reinvestment Act of 2009. Transmitted to Speaker Nancy Pelosi, February 13.

- 2010. Estimated Impact of the American Recovery Reinvestment Act on Employment and Economic Output from July 2010 through September 2010. November.

- 2011. The Budget and Economic Outlook: Fiscal Years 2011 to 2021. January.

DeLong, J. B. 2011. "What Have We Unlearned from Our Great Recession?" Presentation at the American Economic Association, January 7.

DeLong, J. B., and L. H. Summers. 2012. "Fiscal Policy in a Depressed Economy." Brookings Papers on Economic Activity (Spring): 233-97.

Elmendorf, D., D. Lindner, D. Reifschneider, J. Roberts, J. Rudd, R. Tetlow, and D. Wilcox. 2005. "Considerations Pertaining to the Establishment of a Specific, Numerical, Price-Related Objective 
for Monetary Policy." Memo to the Federal Open Market Committee, Board of Governors of the Federal Reserve System, Washington, DC, January 21. Available at http://www.petertulip.com. Elmendorf, D. W., and D. Reifschneider. 2002. "Short-Run Effects of Fiscal Policy with Forward-Looking Financial Markets." National Tax Journal LV (3): 357-86.

Federal Open Market Committee. 2005. "Meeting of the Federal Open Market Committee, February 1-2." Transcript and presentation materials. Available at http://www.federalreserve. gov/monetarypolicy/fomchistorical2005.htm.

- 2012. "Longer-Run Goals and Policy Strategy." Press Release, January 25.

Feldstein, M. 2007. "How to Avert a Recession." The Wall Street Journal, December 5.

Follette, G., and B. Lutz. 2010. "Fiscal Policy in the United States: Automatic Stabilizers, Discretionary Fiscal Policy Actions, and the Economy." FEDS Paper No. 2010-43, Board of Governors of the Federal Reserve System.

Hunt, B., and D. Laxton. 2004. "The Zero Interest Rate Floor (ZIF) and Its Implications for Monetary Policy in Japan." National Institute Economic Review 187 (1): 76-92.

Joint Committee on Taxation. 2009. Estimated Budget Effects of the Revenue Provisions Contained in the Conference Agreement for H.R. 1, The 'American Recovery and Reinvestment Act of 2009'. February 12.

Krugman, P. 2008. "Too Much of a Good Thing." November 28. Available at http://krugman.blogs.nytimes.com/2008/11/ 28/too-much-of-a-good-thing/.

. 2011. "Academic Debate, Real Consequences (Wonkish)." August 26. Available at http://krugman.blogs.nytimes.com/ 2011/08/26/academic-debate-real-consequences-wonkish/\#more23765 .

Leeper, E. 1991. "Equilibria under 'Active' and 'Passive' Monetary and Fiscal Policies." Journal of Monetary Economics 27 (1): $129-47$.

Mankiw, N. G. 2010. Macroeconomics. Worth Publishers.

Mankiw, N. G., and M. Weinzierl. 2011. "An Exploration of Optimal Stabilization Policy." Brookings Papers on Economic Activity (Spring): 209-49. 
Organisation of Economic Cooperation and Development (OECD). 2009. "The Effectiveness and Scope of Fiscal Stimulus." Economic Outlook (April): 105-50 (chapter 3).

Orszag, P. 2011. "Link U.S. Payroll Tax Holiday to Unemployment Rate." June 30. Available at http://www.bloomberg.com/news/ 2011-06-30/payroll-tax-should-be-linked-to-unemployment-ratepeter-orszag.html.

Reifschneider, D., and P. Tulip. 2007. "Gauging the Uncertainty of the Economic Outlook from Historical Forecasting Errors." FEDS Paper No. 2007-60, Board of Governors of the Federal Reserve System.

Reifschneider, D., and J. C. Williams. 2000. "Three Lessons for Monetary Policy in a Low-Inflation Era." Journal of Money, Credit and Banking 32 (4): 936-66.

Romer, C. 2011. "What Do We Know About the Effects of Fiscal Policy? Separating Evidence from Ideology." Speech given at Hamilton College, New York, November 7.

Romer, C., and J. Bernstein. 2009. The Job Impact of the American Recovery and Reinvestment Plan. Washington, DC: Council of Economic Advisors.

Romer, D. 2011. "What Have We Learned About Fiscal Policy from the Crisis?" Paper presented at the IMF Conference on Macro and Growth Policies in the Wake of the Crisis, Washington, DC, March 7-8.

Schmitt-Grohé, S., and M. Uribe. 2010. "The Optimal Rate of Inflation." In Handbook of Monetary Economics, Vol. 3B, ed. B. M. Friedman and M. Woodford, 653-722 (part 4, chapter 13). Elsevier/North Holland.

Summers, L. 2008. "Testimony to House Budget Committee." September 9. Available at http://www.hks.harvard.edu/newsevents/ news/testimonies/summers-testimony-house-budget-committee.

_ 2010. "America's Sensible Stance on Recovery." Financial Times, July 18.

Taylor, J. B., ed. 1999. Monetary Policy Rules. Chicago: University of Chicago Press.

Taylor, J. B. 2000. "Reassessing Discretionary Fiscal Policy." Journal of Economic Perspectives 14 (3): 21-36.

Tulip, P. 2014. "Fiscal Policy and the Inflation Target." Research Discussion Paper No. 2014-02, Reserve Bank of Australia. 
Williams, J. C. 2009. "Heeding Daedalus: Optimal Inflation and the Zero Lower Bound." Brookings Papers on Economic Activity (Fall).

Woodford, M. 2011. "Simple Analytics of the Government Expenditure Multiplier." American Economic Journal: Macroeconomics 3 (1): $1-35$.

Woodford, M., and G. B. Eggertsson. 2004. "Optimal Monetary and Fiscal Policy in a Liquidity Trap." In NBER International Seminar on Macroeconomics, 75-131. MIT Press.

Yellen, J. L. 2006. "Enhancing Fed Credibility." Speech to the Annual Washington Policy Conference sponsored by the National Association for Business Economics (NABE), Washington, DC, March 13.

. 2009. "Closing Panel Presentation." Speech given at the conference on Financial Markets and Monetary Policy, sponsored by the Federal Reserve Board and Journal of Money, Credit and Banking (JMCB), Washington, DC, June 5. 